\title{
ADMINISTRASI EVALUASI DAN PENILAIAN DALAM PENDIDIKAN
}

Muhammad Dahri ${ }^{1}$, Wahyuni Ramadani², Muhammad Arsyam ${ }^{3}$

\author{
${ }^{1}$ Sekolah Tinggi Agama Islam (STAI) Darul Dakwah Wal-Irsyad (DDI) Kota Makassar, Indonesia \\ Email: dahrii.kk@gmail.com \\ ${ }^{2}$ Sekolah Tinggi Agama Islam (STAI) Darul Dakwah Wal-Irsyad (DDI) Kota Makassar, Indonesia \\ Email: wahyuniuni1999@gmail.com \\ ${ }^{3}$ Sekolah Tinggi Agama Islam (STAI) Darul Dakwah Wal-Irsyad (DDI) Kota Makassar, Indonesia \\ Email: arsyam0505@gmail.com
}

\begin{abstract}
Abstrak
Pendidikan sangat penting bagi kehidupan manusia sehingga harus dipenuhi dan dilakukan untuk meningkatkan kualitas hidup manusia. Maka dari itu untuk melihat hasil atau kemajuan dari pendidikan tersebut diperlukan evaluasi dan penilaian untuk menjadi tolak ukur apakah pendidikan tersebut mendapatkan hasil yang baik atau kurang baik. Evaluasi dan Penilaian harus dilakukan oleh suatu lembaga pendidikan, tetapi evaluasi dan penilaian ini memiliki administrasi yang harus diikuti oleh suatu lembaga pendidikan. Artikel ini menjelaskan dengan jelas mengenai administrasi evaluasi dan penilaian dalam pendidikan meliputi definisi,tujuan,fungsi,ruang lingkup,dan sasaran.
\end{abstract}

\section{Kata Kunci: Administrasi, Evaluasi, Penilaian, Dalam Pendidikan.}

\section{PENDAHULUAN}

Pendidikan adalah suatu usaha sadar dan terencana untuk mewujudkan suasana belajar dan proses pembelajaran agar peserta didik secara aktif aktif mengembangkan potensi dirinya untuk memiliki kekuatan spiritual keagamaan, pengendalian diri, kepribadian, kecerdasan, akhlak mulia, serta keterampilan, yang diperlukan dirinya, masyarakat, bangsa, dan negara. Pendidikan Nasional adalah pendidikan yang berdasarkan pancasila dan Undang-Undang Dasar Negara Republik Indonesia Tahun 1945 yang berakar pada milai-nilai Agama, kebudayaan, Nasional Indonesia dan tanggap terhadap tuntutan perubahan zaman.

Pembaruan pendidikan dilakukan terus menerus agar mampu menghadapi tantangan zaman. Dalam era reformasi dan demokrasi pendidikan, tantangan yang dihadapi sitem pendidikan meliputi persoalan-persoalan yang terkait dengan pemerataan, mutu relevansi, dan efisiensi pendidikan.

Untuk mengetahui apakah sebuah tujuan pendidikan sudah tercapai diperlukan sebuah evaluasi dan untuk menentukan kelayakan program dan satuan pendidikan dilakukan sebuah akreditasi. Evaluasi dilakukan dalam rangka pengendalian, penjaminan, dan penetapan mutu pendidikan terhadap berbagai komponen pendidikan pada setiap jalur, jenjang, dan jenis pendidikan sebagai bentuk pertanggungjawaban penyelenggaraan pendidikan yang dilakukan terhadap peserta didik, lembaga, dan program pendidikan. 


\section{PEMBAHASAN}

\section{A. Pengertian Administrasi Evaluasi}

Istilah evaluasi berasal dari bahasa Inggris yaitu “Evaluation”. Menurut Edwin Wand dan Gerald W. Brown, Evaluasi adalah suatu tindakan atau suatu proses untuk menentukan nilai daripada sesuatu. Sesuai dengan pendapat tersebut maka evaluasi pendidikan dapat diartikan sebagai suatu tindakan atau suatu proses untuk menentukan segala sesuatu dalam dunia pendidikan atau segala sesuatu yang ada hubungannya dengan dunia Pendidikan.

Evaluasi merupakan suatu tindakan yang dilakukan oleh seorang evaluator terhadap suatu peristiwa atau kejadian. Tindakan ini mengandung maksud untuk memberikan arti atau makna dari kejadian itu sehingga dapat diproses lebih lanjut. Tindakan tersebut dilakukan atas dasar objektivitas dan integritas. Hal ini dimaksudkan agar hasil yang diperoleh dapat memberikan kepuasan bagi semua pihak.

Evaluasi dimaksudkan untuk menentukan nilai sesuatu. Dari hasil evaluasi kita dapat menentukan apakah sesuatu itu mempunyai nilai atau tidak. Dengan kata lain, evaluasi dapat menunjukkan kualitas sesuatu.

Evaluasi Program adalah suatu rangkaian kegiatan yang dilakukan dengan sengaja untuk melihat tingkat keberhasilan program. Ada beberapa pengertian tentang "program" itus sendiri. Di dalam kamus tertulis:

1) Program adalah rencana,

2) Program adalah kegiatan yang direncanakan dengan saksama.

Melakukan evaluasi program adalah kegiatan yang dimaksudkan untuk mengetahui seberapa tinggi tingkat keberhasilan dari kegiatan yang direncanakan.

\section{B. Tujuan dan Fungsi Evaluasi}

Sebagaimana kita ketahui, evaluasi banyak digunakan dalam berbagai bidang kegiatan, antara lain dalam kegiatan bimbingan dan penyuluhan, kegiatan supervisi, kegiatan seleksi, dan kegiatan pengajaran. Setiap bidang dan kegiatan menuntut tujuan yang berbeda. Dalam kegiatan bimbingan dan penyuluhan, tujuan evaluasi adalah untuk memperoleh informsi secara menyeluruh mengenai karakteristik anak didik sehingga dapat diberikan bimbingan dan penyuluhan yang sebaik-baiknya. Dalam kegiatan supervisi, tujuan evaluasi adalah untuk menentukan keadaan suatu situasi pendidikan pada umumnya dan situasi belajar-mengajar 
(teaching learning situation) pada khususnya sehingga dapat diusahakan langkah-langkah perbaikan dan atau peningkatan mutu pendidikan dan pengajaran di suatu sekolah.

Tujuan evaluasi program antara lain adalah:

1) Untuk mengumpulkan/memperoleh data tentang hasil-hasil yang telah dicapai pada akhir suatu periode pelaksanaan program.

2) Untuk mengetahui kesulitan atau hambatan yang dialami dalam pelaksanaan program

3) Untuk memperoleh dasar bagi pembuatan atau pengambilan keputusan dalam penyusunan langkah-langkah/kebijakan yang akan ditempuh dalam periode berikutnya.

4) Untuk menghindari gangguan/hambatan, serta menjamin efektivitas dan efisiensi kerja pada periode berikutnya.

Adapun Fungsi dari evaluasi program yaitu:

1) Bagi pelaksana program berguna untuk dasar penyusunan laporan sebagai kelengkapan pertanggungjawaban tugas

2) Bagi lembaga atau badan yang membawahi pelakasana program mempunyai data yang akurat sebagai bahan pengambilan keputusan, khususnya untuk kepentingan supervisi

3) Bagi evaluator luar dapat bertindak dengan obyektif karena berpijak pada data yang dikumpulkan dengan cara-cara sesuai dengan aturan tertentu.

\section{Ruang Lingkup Evaluasi}

Ruang lingkup evaluasi ini akan menghubungkan apa dan berapa lama evaluasi akan dilaksanakan meliputi elemen-elemen yang bersangkut paut dengan pelaksanaan pendidikan yaitu: kurikulum, strategi dan metode pembelajaran, alat-alat atau media, siswa dan guru. Maka kegiatan evaluasi ini memerlukan informasi mengenai:

1) Tujuan diadakannya program

2) Strategi dan perencanaan

3) Proses dan pelaksanaan

4) Hasil dan dampak

Selanjtnya adalah terkait dengan beerapa lama evaluasi dilakukan, maka jenis evaluasinya adalah:

1) Short term evaluation, dilakukan sebagai kegiatan "check up" terhadap treatment baru yang diintrodusir. Waktu yang digunakan paling lama satu minggu. 
2) Medium term evaluation, dilakukan untuk mengevaluasi suatu proyek kurikulum yang dapat dilaksanakan antara satu sampai empat tahun

3) Long term survey, yaitu evaluasi yang dilakukan terhadap sekolah yang melakukan suatu program dengan menggunakan berbagai instrumen. Tujuannya adalah mengumpulkan data secara terus menerus tentang standar pencapaian tujuan pembelajaran di semua tingkat dan semua bidang pembelajaran.

\section{Pengertian Administrasi Penilaian Dalam Pendidikan}

Penilaian pendidikan menurut Marito (2012) adalah proses pengumpulan dan pengolahan informasi untuk menentukan pencapaian hasil belajar peserta didik. Maulana (2009) berpendapat bahwa penilaian pendidikan merupakan suatu proses penentuan nilai atau keputusan dalam bidang pendidikan atau segala sesuatu yang ada hubungannya dengan bidang pendidikan. Penentuan keputusan itu didahului dengan kegiatan pengumpulan data atau informasi sehingga seorang pimpinan dapat menyusun auatu kebijakan terhadap suatu program yang sedang dikembangkan atau yang sedang dilaksanakan. Setiap orang yang terlibat dalam pendidikan, bagaimanapun macam dan ruang lingkup keputusan pendidikan itu, keputusan tersebut memerlukan informasi yang lengkap dan tepat. Informasi semacam ini akan diperoleh melalui penilaian.

\section{1) Konsep Dasar Penilaian Pendidikan}

Kita sudah paham bahwa dalam proses pendidikan di sekolah selalu melibatkan unsur penilaian. Namun, keberadaan unsur ini tidak senantiasa dapat memberikan fungsi yang bersifat komprehensif bagi sekolah terutama yang menyangkut perbaikan dan pengembangannya.. Banyak faktor yang berpengaruh berkenaan dengan fungsi penilaian dalam peningkatan program sekolah, salah satunya adalah makna yang ditafsirkan dari konsep penilaian itu sendiri.

Pada kesempatan ini, penilaian akan didefinisikan dalam konteks pengembangan program pendidikan. Oleh karena itu, sangat penting dipahami bahwa tujuan penilaian bukan untuk membuktikan, akan tetapi memperbaiki. Kerangka pemikiran ini tampak ada kaitan yang erat antara penilaian dan mutu pendidikan di sekolah. Selanjutnya konsep penilaian yang akan dibicarakan bertitik tolak dari tujuan penilaian tersebut.

Penilaian pendidikan merupakan suatu proses penentuan nilai atau keputusan dalam bidang pendidikan atau segala sesuatu yang ada hubungannya dengan bidang pendidikan. 
Penentuan keputusan itu didahului dengan kegiatan pengumpulan data atau informasi sehingga seorang pimpinan dapat menyusun auatu kebijakan terhadap suatu program yang sedang dikembangkan atau yang sedang dilaksanakan. Setiap orang yang terlibat dalam pendidikan, bagaimanapun macam dan ruang lingkup keputusan pendidikan itu, keputusan tersebut memerlukan informasi yang lengkap dan tepat.

Informasi semacam ini akan diperoleh melalui penilaian. Penilaian sebagai kegiatan pemeriksanaan yang sistematis dari peristiwa-peristiwa yang terjadi dan akibatnya pada saat program dilaksanakan pemeriksaan yang diarahkan untuk membantu memperbaiki program itu dan program lain yang memiliki tujuan yang sama.

\section{2) Tujuan dan Sasaran Penilaian Pendidikan}

Kegiatan penilaian pendidikan mempunyai tujuan-tujuan sebagai berikut :

a. Untuk memperoleh dasar bagi pertimbangan pada akhir suatu periode kerja.

b. Untuk menjamin cara bekerja yang efektif dan efisien.

c. Untuk memperoleh fakta-fakta tentang kesukaran-kesukaran dan untuk menghindarkan situasi-siatuasi yang dapat merusak.

d. Untuk memajukan kesanggupan para guru dan orang tua murid dalam mengembangkan organisasi sekolah.

Sasaran penilaian yang dimaksud ialah segala sesuatu yang menjadi titik pusat pengamatan karena penilaian menginginkan informasi tentang sesuatu tersebut. Dengan menggunakan diagram tentang transformasi menurut Andini (2013) maka sasaran penilaian untuk unsur-unsurnya meliputi: input, transformasi, dan output (keluaran).

a) Input adalah untuk mengetahui pribadi seorang siswa yang utuh, dapat dilakukan macam-macam bentuk tes sebagai alat untuk mengukur. Aspek yang bersifat rohani setidaknya mencakup empat hal:

- Kemampuan seorang siswa yang akan mengikuti program dalam memasuki sekolah, guru akan melihat kemampuan siswa. Alat ukur yang digunakan untuk mengukur kemampuan ini disebut tes kemampuan atau attietude test.

- Kepribadian adalah sesuatu yang biasa terdapat disetiap diri manusia dengan menampakan kepribadian itu dari sikap tingkah laku yang dimiliki manusia. Alat untuk mengetahui kepribadian itu disebut tes kepribadian atau personality test. 
- Sikap-sikap adalah termasuk kedalam bagian dari tingkah laku yang dimiliki manusia, namun ada hal yang lebih menonjol dari sikap dan sangat dibutuhkan dalam sebuah pergaulan agar dapat mendapatkan informasi dari pergaulannya. Alat yang dapat mengetahui keadaan sikap sering dinamakan tes sikap atau attitude test.

- Tes Intelegensi atau sering dikenal dengan intelligence anetient. Namun, sebenarnya IQ itu bukan lah intelegensi. IQ berbeda dengan intelegensi karena IQ hanyalah angka yang memberi petunjuk mengenai tinggi rendahnya intelegensi seseorang. Dengan pengertian ini maka kurang benarlah jika ada orang mengatakan "IQ JONGKOK" karena IQ hanyalah berupa angka. Mestinya Iq rendah diartikan bahwa angkanya rendah.

b) Transformasi adalah unsur yang terdapat dalam transformsi semuanya dapat menjadi sasaran atau objek penilaian demi diperolehnya hasil pendidikan yang diharapkan. Untuk transformasi yang menjadi objek penilaian antara lain:

- Kurikulum/materi

- Metode dan cara penilaian

- Sarana pendidikan/media

- Sistem administrasi

- Guru dan personal lainya

c) Output adalah penilaian terhadap lulusan suatu sekolah dikurikulum untuk mengetahui seberapa jauh tingkat pencapaian/prestasi belajar mereka selama mengikuti progam. Alat yang digunakan untuk mengukur pencapaian ini disebut tes pencapaian atau achieviment test.

Kecendrungan yang ada sampai saat ini adalah bahwa guru hanya menilai prestasi belajar aspek kognitif atau kecerdasan saja. Alatnya adalah tes tertulis. Aspek psikomotorik, apalagi afektif sangat jarang diterapkan oleh guru. Akaibatnya, dapat kita buktikan yakni bahwa para lulusan hanya mengetahui teori tetapi tidak terampil melakukan keterampilan, juga tidak mampu mengaplikasikan pengetahuan yang sudah mereka ketahui. Lemahnya pembelajaran dan evaluasi terhadap aspek afektif ini, jika kita mau introfeksi, telah berakibat merosotnya akhlak para lulusan, yang selanjutnya berdampak luas pada merosotnya anak bangsa. 


\section{3) Fungsi Penilaian}

Fungsi penilaian pada akhir satuan pelajaran itu ditekankan kepada perbaikan proses belajar mengajar yang diselenggarakan berdasarkan satuan pelajaran tersebut. Penilaian pada akhir program pengajaran mempunyai fungsi yang berlainan. Fungsinya ditekankan pada penentuan keberhasilan belajar setiap murid. Penentuan semacam itu biasanya dilakukan untuk keperluan pemberian nilai rapor, penentuan kenaikan kelas, seleksi dan sebagainya.

Penilaian pada akhir program pengajaran ini tidak lagi berfungsi untuk memperbaiki proses belajar mengajar karena pada akhir program pengajaran itu guru telah berkali-kali melakukan penilaian formatif pada setiap akhir satuan pelajaran. Penilaian dilakukan untuk menentukan nilai, atau kenaikan kelas, atau seleksi ini juga merupakan penilaian sumatif.

Adapun fungsi penilaian dalam proses pembelajaran sebagai berikut:

a. Sebagai bahan diagnosis dan pengembangan dari hasil penilaian dapat digunakan sebagai dasar mendiagnosis kelemahan dan keunggulan siswa, serta hambatan yang menyertainya, hasil ini juga dapat digunakan sebagai bahan pengembangan kualitas pembelajaran siswa.

b. Sebagai bahan seleksi dari hasil penilaian dapat digunakan sebagai dasar seleksi penempatan siswa menurut jenis jurusan atau jabatannya.

c. Sebagai bahan pertimbangan kenaikan kelas dari hasil penilaian dapat digunakan sebagai dasar untuk menentukan apakah siswa yang bersangkutan dapat naik kelas atau tidak, sebagai wujudnya adalah nilai atau skor dalam rapor siswa.

d. Sebagai bahan pertimbangan untuk penempatan dari hasil penilai yang dapat digunakan sebagai dasar seleksi penempatan siswa berdasarkan kemampuan yang mereka miliki.

Secara lebih rinci, Purwanto (dalam Arifin, 2012) mengelompokkan fungsi penilaian dalam kegiatan evaluasi atau penilaian pendidikan dan pengajaran, yakni:

a) Untuk mengetahui kemajuan dan perkembangan serta keberhasilan siswa setelah mengalami atau melakukan kegiatan belajar selama jangka waktu tertentu,

b) Untuk mengetahui tingkat keberhasilan program pengajaran. Pengajaran sebagai suatu sistem terdiri dari beberapa komponen yang saling berkaitan satu sama lain. Komponenkompenen yang dimaksud adalah: tujuan, materi atau bahan pengajaran, metode dan kegiatan belajar mengajar, alat dan sumber pelajaran, dan prosedur serta alat evaluasi.

c) Untuk keperluan Bimbingan Konseling (BK). Hasil-hasil penilaian dalam kegiatan evaluasi yang telah dilaksanakan oleh guru terhadap siswanya dapat dijadikan sumber informasi atau data bagi pelayanan BK oleh para konselor sekolah atau guru pembimbing 
lainnya, seperti halnya: (a) untuk Membuat diagnosis mengenai kelemahan-kelemahan dan kekuatan atau kemampuan siswa, (b) untuk mengetahui dalam hal-hal apa seseorang atau sekelompok siswa memerlukan pelayanan remedial, (c) sebagai dasar dalam menangani kasus-kasus tertentu diantara siswa, (d) sebagai acuan dalam melayani kebutuhan-kebutuhan siswa dalam rangka bimbingan karir.

d) Untuk keperluan pengembangan dan perbaikan kurikulum sekolah yang bersangkutan, sehingga pihak sekolah dapat mengembangkan proses pembelajaran di masa yang akan datang agar tercipta suasana yang lebih baik dan kondusif.

\section{KESIMPULAN}

Dari bebagai penjelasan mengenai materi administrasi evaluasi dan penilaian dalam pendidikan maka selaku penulis artikel ini dapat memberikan pemahaman dalam wacana pengembangan intelektual bagi kami dari tim penulis secara khusus dan para pembaca secara umum, adapun kesimpulan yang dapat kami sajikan sebagai berikut:

a. Evaluasi adalah suatu tindakan atau suatu proses untuk menentukan nilai daripada sesuatu.

Sesuai dengan pendapat tersebut maka evaluasi pendidikan dapat diartikan sebagai suatu tindakan atau suatu proses untuk menentukan segala sesuatu dalam dunia pendidikan atau segala sesuatu yang ada hubungannya dengan dunia pendidikan.

b. Penilaian pendidikan sebagai proses pengumpulan dan pengolahan informasi untuk mengukur pencapaian hasil belajar peserta didik mencakup: penilaian otentik, penilaian diri, penilaian berbasis portofolio, ulangan, ulangan harian, ulangan tengah semester, ulangan akhir semester, ujian tingkat kompetensi, ujian mutu tingkat kompetensi, ujian nasional, dan ujian sekolah/madrasah. Standar Penilaian Pendidikan adalah kriteria mengenai mekanisme, prosedur, dan instrumen penilaian hasil belajar peserta didik.

c. Penilaian hasil belajar oleh pendidik yang dilakukan secara berkesinambungan bertujuan untuk memantau proses dan kemajuan belajar peserta didik serta untuk meningkatkan efektivitas pembelajaran 


\section{DAFTAR PUSTAKA}

Janna, N. M., A., kurnia, A. d., \& Arsyam, M. (2021, January 14). Administrasi Keuangan Dalam Pendidikan. https://doi.org/10.31219/osf.io/hmvcf

Arsi, A., I., \& Arsyam, M. (2021, January 16). Artikel Administrasi Tata Kelola Dalam Pendidikan. https://doi.org/10.31219/osf.io/wsd9r

Arsyam, M., \& Alwi, A. M. (2020). MANAJEMEN HIDUP DALAM PERSPEKTIF AL-QUR'AN.

Makmur, Z., Arsyam, M., \& Alwi, A. M. S. (2020). Strategi Komunikasi Pembelajaran Di Rumah Dalam Lingkungan Keluarga Masa Pandemi. KOMUNIDA: Media Komunikasi dan Dakwah, 10(02), 231-241.

Baharun, H. (2016). Penilaian Berbasis Kelas pada Pembelajaran Pendidikan Agama Islam di Madrasah. MODELING: Jurnal Program Studi PGMI, 3(2), 204-216.

Arsyam, M. (2020). Manajemen pendidikan islam.

Ependi, U., Putra, A., \& Panjaitan, F. (2019). Evaluasi tingkat kebergunaan aplikasi Administrasi Penduduk menggunakan teknik System Usability Scale. Register: Jurnal Ilmiah Teknologi Sistem Informasi, 5(1), 63-76.

Arsyam, M. (2021). BAHAN AJAR ADMINISTRASI PENDIDIKAN.

Astuti, S. (2016). Penerapan supervisi akademik untuk meningkatkan kompetensi guru dalam menyusun administrasi penilaian di sd laboratorium uksw. Scholaria: Jurnal Pendidikan dan Kebudayaan, 6(1), 117-126.

WEKKE, I. S. EVALUASI PENGEMBANGAN KURIKULUM MADRASAH MINORITAS MUSLIM: TINJAUAN DARI PAPUA BARAT.

Muslim, A. Q., \& Wekke, I. S. (2018). Model Penilaian Kinerja Guru. Al-TA'DIB: Jurnal Kajian Ilmu Kependidikan, 11(1), 37-54. 